\title{
Traditional uses and seed chemical composition of Jatropha spp. (Euphorbiaceae) in Tehuacán-Cuicatlán, México
}

\author{
Nancy Yazmín Hernández-Nicolás ${ }^{1}$, Leobigildo Córdova-Téllez ${ }^{1 *}$, \\ Angélica Romero-Manzanares ${ }^{2}$, Jaime Jiménez-Ramírez ${ }^{3}$ \& Mario Luna-Cavazos ${ }^{2}$ \\ 1. Posgrado en Recursos Genéticos y Productividad, Colegio de Postgraduados. Km. 36.5 Carretera México-Texcoco. \\ 56 230, Montecillo, Texcoco, Estado de México, México; nancyazmin379@gmail.com, 1cordova@colpos.mx \\ 2. Posgrado en Botánica, Colegio de Postgraduados. Km. 36.5 Carretera México-Texcoco. 56 230, Montecillo, Texcoco, \\ Estado de México, México; dahly@colpos.mx,mluna@colpos.mx \\ 3. Facultad de Ciencias, Universidad Nacional Autónoma de México. Ciudad Universitaria, circuito exterior. Col. \\ Copilco El Bajo, Del. Coyoacán. AP 04 510. México, DF; jjimenez_ramirez@yahoo.com \\ * Correspondence.
}

\section{Received 15-VI-2017. Corrected 20-X-2017. Accepted 20-XI-2017.}

\begin{abstract}
The Tehuacán-Cuicatlán Biosphere Reserve in México holds genetic richness and endemism for the genus Jatropha, but the specific use of the plants and the seed chemical profiles are still unknown. We recorded the traditional forms of use of Jatropha species, and analyzed the chemical composition of Jatropha spp. seeds. For this, a semi-structured survey was conducted in 15 towns, and 20 interviews were applied in each one between May and August 2012 to estimate the Significant Use Level and Relative Use Value per species. Besides, seeds from J. neopauciflora, J. rufescens, and J. rzedowskii were collected between August and October 2013, and to seed flour samples we determined total lipids by the Soxhlet method, crude protein by the Kjendahl method, and ashes according to AOAC methods; fatty acid profile and phorbol esters were determined by gas chromatography and by HPLC, respectively. The species J. neopauciflora, J. oaxacana, J. rufescens, J. ciliata, and $J$. rzedowskii, are used as traditional medicine, food, and ornaments, except for J. ciliata, for which none use was recorded. The Significant Use Level as food was found not significant, but for medicinal purposes, $J$. neopauciflora obtained the highest Relative Use Value (9.0\%). The latex is used to treat 13 disorders, including dental problems and oral diseases with a Significant Use Level of $32.9 \%$; it is also used as a hemostatic. The protein content among species varied from 23.37 to $26.06 \%$, and total lipids from 34.79 to $36.60 \%$. The principal unsaturated fatty acids were oleic (25.08 to $30.09 \%)$ and linoleic (44.55 to $48.46 \%$ ), and the saturated fatty acids were palmitic (10.11 to $16.50 \%)$ and stearic $(9.47$ to $11.15 \%)$. Phorbol esters, the main cause of seed's toxicity, were absent in J. neopauciflora, J. rufescens, and J. rzedowskii. In conclusion, the Significant Use Level of Jatropha species studied was low, with little cultural acceptance and sporadic utilization. The Relative Use Value was important for medicinal purposes, especially for J. neopauciflora. The dehulled seeds of $J$. neopauciflora, J. rufescens, and J. rzedowskii are potentially useful as food, having high protein contents, and unsaturated oleic and linoleic fatty acids. With this study we report three non-toxic Jatropha species and recommend to scientifically validate the antimycotic use of J. neopauciflora latex. Rev. Biol. Trop. 66(1): 266279. Epub 2018 March 01.
\end{abstract}

Key words: infections; dental hygiene; fatty acids; Jatropha; phorbol esters; proteins; traditional uses.

The genus Jatropha (Euphorbiaceae) consists of 175 species distributed throughout the tropical and subtropical regions of the world (Webster, 1994). The name Jatropha is derived from the Greek words jatros (physician) and trophe (food), suggesting that species of the genus have been traditionally used for their medicinal properties and nutritional qualities. The genus contributes with 45 taxa $(20 \%$ of the world total) to the Mexican biodiversity, of which 35 taxa $(77 \%)$ are endemic and are found distributed in 15 states (Martínez et al., 2002).

The existence of non-toxic (absence of phorbol esters) Jatropha genotypes have been 
registered only in México (Maghuly, Jankowicz-Cieslak, Till, \& Laimer, 2015). Seeds of a genotype of Jatropha curcas L. are eaten in regions of Veracruz and Northern Puebla (Martínez-Herrera, Siddhuraju, Francis, Dávila-Ortíz, \& Becker, 2006), and J. platyphylla Müll. Arg seeds are eaten roasted or used as an ingredient in regional dishes in Sinaloa (Makkar, Kumar, Oyeleye, Akinleye, AnguloEscalante, \& Becker, 2011). Currently, most of the studies have been conducted in $J$. curcas with a wide variety of uses (Kumar \& Sharma, 2008; Abdelgadir \& Staden, 2013; Agbogidi, Akparobi, \& Eruotor, 2013), but nowadays, the most important one is related to the physicalchemical properties of the seed oil, which make it suitable for biofuels production.

The use of other species of the genus is related to the phytochemical properties of the seeds and to the latex extracted from the leaves and stems. The active ingredients of the latex of several species have been demonstrated to be hemostatic (Osoniyi \& Onajobi, 2003; Oduola, Adeosun, Oduola, Avwioro, \& Oyeniyi, 2005), antibacterial (Aiyelaagbe, Adesogan, Ekundayo, \& Adeniyi, 2000; Canales et al., 2005), antifungal (Hamza et al., 2006), anti-malarial and anti-parasitic (Baraguey, Blond, Correia, Pousset, Bodo, \& Auvin-Guette, 2000), and insecticidal (Bullangpoti, Khumrungsee, Pluempanupat, Kainoh, \& Saguanpong, 2011). Extensive reviews in medicinal purposes have been documented for $J$. curcas (Reddy-Prasad, Izam, \& Rahman-Khanwe, 2012) and for $J$. gossypiipholia (Félix-Silva et al., 2014).

The use of this plant parts as food is relevant from the perspective of traditional knowledge, which adds value to the wild plants because they provide fruit, seeds, leaves and other edible botanical structures. However, this use is limited to two phorbol ester free species identified so far. Ethnic population groups possess knowledge of wild plant species, and in the future, their information could contribute to solve diverse social problems, such as the scarcity of food, energy, and medicine (Abdelgadir \& Staden, 2013).
Currently, the traditional knowledge of medicinal plants has acquired special relevance due to destruction of natural habitats. Nevertheless, the analysis of ethnobotanical data is complex because the information is largely descriptive (Alexiades, 1996). For this reason, quantitative techniques have been developed, and these enable the estimation of the relative importance of useful species and their comparison with others in the same cultural context (Bruni, Ballero, \& Poli, 1997; Ankli, Sticher, \& Heinrich, 1999). These techniques are based on the consensus of the informers as quantitative criteria, under the assumption that a high number of citations for a specific use represent social historical-validation of the relationship between the plants' use and health problems; it is also an indication of the presence of some components with pharmacological applications (Hidalgo-Báez, Ricard, Gaviria, \& Estrada, 1999).

Taking into account the richness of the genus Jatropha in the Tehuacán-Cuicatlán Biosphere Reserve, México (Hernández-Nicolás, Córdova-Téllez, Romero-Manzanares, Jiménez-Ramírez, Lobato-Ortiz, \& SánchezCuevas, 2015), and the potential use of the chemical composition of seeds, in this study we surveyed the traditional forms of use of the species, and analyzed the chemical composition of the Jatropha seeds. Variation in the chemical composition in the Jatropha spp. seeds was expected, which could explain or confirm some traditional uses that residents of the region have assigned to the different species.

\section{MATERIALS AND METHODS}

Study area: The Tehuacán-Cuicatlán Biosphere Reserve is located in the Southeastern part of the state of Puebla and the Northeast-

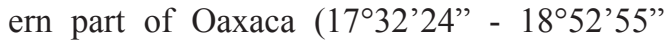
N \& 96 59'24" - 9748' 43” W), altitude 200 to 3500 masl. The vegetation types include Xerophytic Scrub, Tropical Deciduous Forest, Thorn Scrub, Oak Forest, Pine-Oak Forest, and Grassland (DOF, 1998). According to the Köppen classification, modified by García (1990), 
the climate is $\mathrm{BS}_{0} \mathrm{hw} "(\mathrm{w})(\mathrm{e})(\mathrm{g})$, semi-arid with mean annual temperature of $21^{\circ} \mathrm{C}$ and mean annual precipitation of $380 \mathrm{~mm}$. The ethnic groups living in the region are Popoloca, Mixteco, Ixcateco, Cuicateco, Nahua, Chocholteco, Chinanteco, and Mazateco, and the main activity is agriculture.

Sample size: Our study included a review of herbarium specimens of several herbaria in México (Herbario Nacional MEXUUNAM; Herbario-Hortorio CHAPA-COLPOS; Herbario de Plantas Útiles XOLO-UACH; Herbario de Ciencias Forestales CHP-UACH; Herbario de Preparatoria Agrícola UACH; Herbario del Instituto de Ecología A. C., México (IE-Bajio)-IEB; Red Mundial sobre Biodiversidad REMIB-CONABIO), and we obtained the geographic distribution of 67 specimens of Jatropha which corresponded to 31 towns. To establish the sample number of towns to apply the surveys, we used the equation proposed by Murray (1988):

$$
n=\frac{N S^{2}}{\frac{B_{\mu}^{2}}{t^{2}}(N-1)+S^{2}}
$$

where:

$n=$ sample size; $N=$ population size (31 sites);

$S^{2}=$ weighted variance of the population (maximum variance 0.25$)$; = precision expressed in hundredths $(0.20$, equivalent to $20 \%) ; t=$ value of distribution " $z$ " for a given reliability (for populations of less than 100 registers, distribution " $t$ " $=2.0860$ ). With a precision error of 20 $\%$, the sample size obtained was 15 towns for survey application. The towns were selected taking the following factors into account: (1) the number of species verified taxonomically distributed in the wild plant populations that belong to each town; (2) the accessibility of the plant populations, and the disposition of the town's authorities (Fig. 1; Table 1).

Characterization of traditional uses: Semi-structured ethnobotanical questionnaires were applied between May and August of 2012

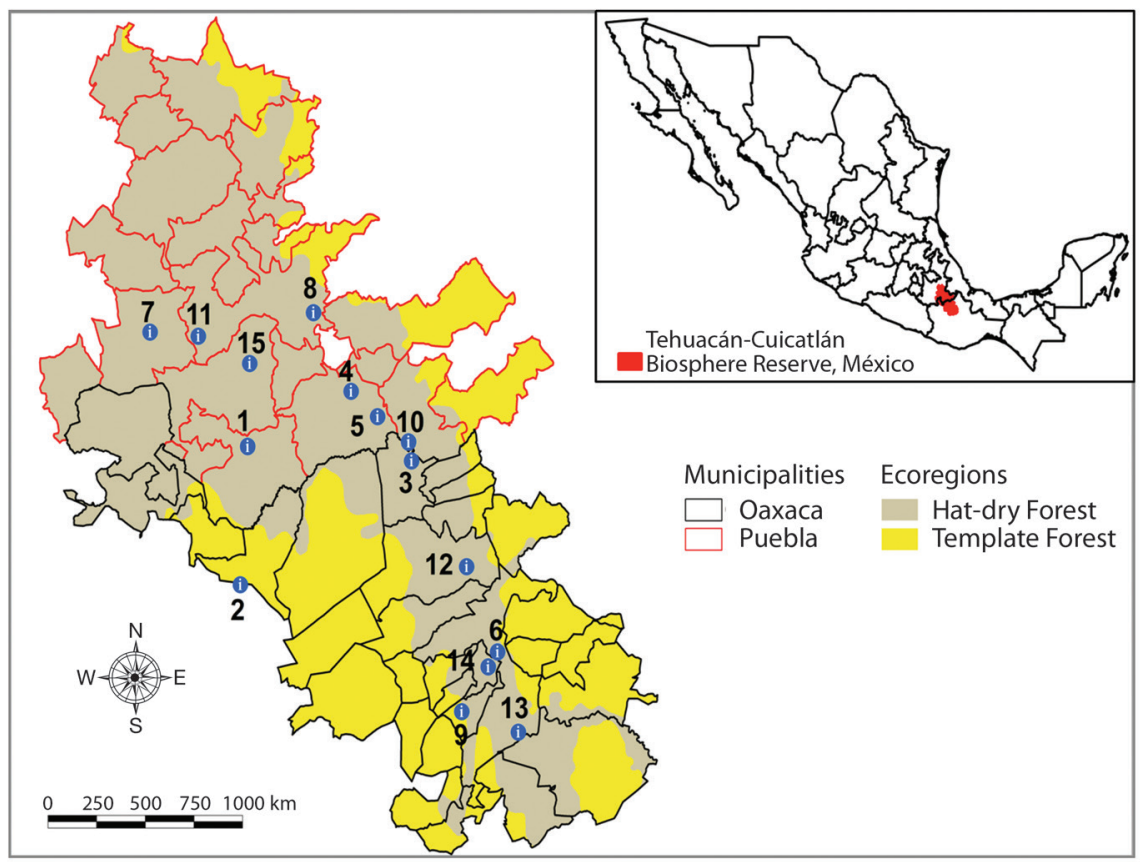

Fig. 1. Selected survey towns in the Tehucán-Cuicatlán Biosphere Reserve, states of Puebla and Oaxaca, México. 
TABLE 1

Geographic coordinates for each species found in the selected survey towns (Fig. 1)

in the Tehucán-Cuicatlán Biosphere Reserve, states of Puebla and Oaxaca, México

\begin{tabular}{|c|c|c|c|}
\hline ID & Town & Species & Geographic Coordinates \\
\hline 1 & Caltepec & $\begin{array}{l}\text { J. neopauciflora } \\
\text { J. oaxacana }\end{array}$ & $18^{\circ} 9 ’ 29.92 ” \mathrm{~N}, 97^{\circ} 28^{\prime} 15^{\prime \prime} \mathrm{W}$ \\
\hline 2 & La Mexicana & J. rufescens & $17^{\circ} 54^{\prime} 51.3^{\prime \prime} \mathrm{N}, 97^{\circ} 28^{\prime} 7.5^{\prime \prime} \mathrm{W}$ \\
\hline 3 & San Gabriel Casa Blanca & $\begin{array}{l}\text { J. neopauciflora } \\
\text { J. rzedowskii }\end{array}$ & $\begin{array}{l}18^{\circ} 10^{\prime} 14.9^{\prime \prime} \mathrm{N}, 97^{\circ} 10^{\prime} 27.4^{\prime} \mathrm{W} \\
18^{\circ} 10^{\prime} 23^{\prime \prime} \mathrm{N}, 97^{\circ} 10^{\prime} 37.9^{\prime \prime} \mathrm{W}\end{array}$ \\
\hline 4 & San Jeronimo Axochitlán & $\begin{array}{l}\text { J. neopauciflora } \\
\text { J. rzedowskii }\end{array}$ & $18^{\circ} 14^{\prime} 50.7^{\prime \prime} \mathrm{N}, 97^{\circ} 14^{\prime} 54.3^{\prime \prime} \mathrm{W}$ \\
\hline 5 & San José Axuxco & $\begin{array}{l}\text { J. neopauciflora } \\
\text { J. rzedowskii }\end{array}$ & $18^{\circ} 13^{\prime} 13.1^{\prime \prime} \mathrm{N}, 97^{\circ} 13^{\prime} 57.1^{\prime \prime} \mathrm{W}$ \\
\hline 6 & San Juan Bautista Cuicatlán & $\begin{array}{l}\text { J. neopauciflora } \\
\text { J. rzedowskii }\end{array}$ & $\begin{array}{l}17^{\circ} 49^{\prime} 48.3^{\prime \prime} \mathrm{N}, 96^{\circ} 58^{\prime} 28.2^{\prime \prime} \mathrm{W} \\
17^{\circ} 49^{\prime} 58^{\prime \prime} \mathrm{N}, 96^{\circ} 58^{\prime} 41.7^{\prime \prime} \mathrm{W}\end{array}$ \\
\hline 7 & San Nicolás Tepoxtitlan & $\begin{array}{l}\text { J. neopauciflora } \\
\text { J. rzedowskii }\end{array}$ & $\begin{array}{l}18^{\circ} 20^{\prime} 28^{\prime \prime} \mathrm{N}, 97^{\circ} 39^{\prime} 23.7^{\prime \prime} \mathrm{W} \\
18^{\circ} 20^{\prime} 25.1^{\prime \prime} \mathrm{N}, 97^{\circ} 39^{\prime} 29.2^{\prime \prime} \mathrm{W}\end{array}$ \\
\hline 8 & San Pablo Tepetzingo & J. neopauciflora & $18^{\circ} 27^{\prime} 2.9^{\prime \prime} \mathrm{N}, 97^{\circ} 19^{\prime} 13.2^{\prime \prime} \mathrm{W}$ \\
\hline 9 & San Pedro Jaltepetongo & $\begin{array}{l}\text { J. ciliata } \\
\text { J. neopauciflora } \\
\text { J. oaxacana }\end{array}$ & $\begin{array}{l}17^{\circ} 41^{\prime} 23.1^{\prime \prime} \mathrm{N}, 97^{\circ} 1^{\prime} 55.5^{\prime \prime} \mathrm{W} \\
17^{\circ} 43^{\prime} 59.1{ }^{\prime \prime} \mathrm{N}, 96^{\circ} 59^{\prime} 26.2^{\prime \prime} \mathrm{W}\end{array}$ \\
\hline 10 & San Rafael & $\begin{array}{l}\text { J. neopauciflora } \\
\text { J. rzedowskii }\end{array}$ & $18^{\circ} 12^{\prime} 31.3^{\prime \prime} \mathrm{N}, 97^{\circ} 7^{\prime} 48.3^{\prime \prime} \mathrm{W}$ \\
\hline 11 & Santa Ana Teloxtoc & $\begin{array}{l}\text { J. neopauciflora } \\
\text { J. rzedowskii }\end{array}$ & $\begin{array}{l}18^{\circ} 19^{\prime} 56.6^{\prime \prime} \mathrm{N}, 97^{\circ} 33^{\prime} 11.7^{\prime \prime} \mathrm{W} \\
18^{\circ} 22^{\prime} 3^{\prime \prime} \mathrm{N}, 97^{\circ} 34^{\prime} 30.2^{\prime \prime} \mathrm{W}\end{array}$ \\
\hline 12 & Santa María Tecomavaca & $\begin{array}{l}J . \text { neopauciflora } \\
\text { J. rzedowskii }\end{array}$ & $\begin{array}{l}17^{\circ} 49^{\prime} 48.3^{\prime \prime} \mathrm{N}, 96^{\circ} 58^{\prime} 28.2^{\prime \prime} \mathrm{W} \\
17^{\circ} 51^{\prime} 55.9^{\prime \prime} \mathrm{N}, 97^{\circ} 1^{\prime} 51.7^{\prime \prime} \mathrm{W}\end{array}$ \\
\hline 13 & Santiago Dominguillo & J. neopauciflora & $17^{\circ} 38^{\prime} 36.8^{\prime \prime} \mathrm{N}, 96^{\circ} 54^{\prime} 58.5^{\prime \prime} \mathrm{W}$ \\
\hline 14 & Valerio Trujano & $\begin{array}{l}J . \text { neopauciflora } \\
\text { J. rzedowskii }\end{array}$ & $17^{\circ} 46^{\prime} 21.6^{\prime \prime} \mathrm{N}, 96^{\circ} 59^{\prime} 50.2^{\prime \prime} \mathrm{W}$ \\
\hline 15 & Zapotitlán de las Salinas & $\begin{array}{l}\text { J. neopauciflora } \\
\text { J. rzedowskii }\end{array}$ & $\begin{array}{l}18^{\circ} 20^{\prime} 35.2^{\prime \prime} \mathrm{N}, 97^{\circ} 31^{\prime} 6.2^{\prime \prime} \mathrm{W} \\
18^{\circ} 20^{\prime} 26.7^{\prime \prime} \mathrm{N}, 97^{\circ} 30^{\prime} 55.9^{\prime \prime} \mathrm{W}\end{array}$ \\
\hline
\end{tabular}

to determine the local knowledge, importance and main uses of the Jatropha species distributed in the study area. The questions were: Do you know the plant we are showing (herbarium specimen or photograph)? What is the name for which you know this plant (common name)? Does this plant have some importance for you? What are the uses or why is it important for you (medicinal, ornamental, artisanal, forage, as food, other)? Specify the used or disorder treated. What part of the plant do you use (root, shot, leaves, flower, fruit, and seed)? What is the preparation procedure that you follow to use the part of the plant (infusion or tea, directly consumed, grounded, directly applied, cooked? Who teaches you the use of the plant? The species distributed in the study region were $J$. ciliata Sessé, J. neopauciflora Pax, J. oaxacana J. Jiménez Ram. \& R. Torres, J. rufescens Brandegee, and J. rzedowskii J. Jiménez Ram. (Fig. 2) (Hernández-Nicolás et al., 2015). The plant names have been checked with www.theplantlist.org (accesing June 4, 2016).

In each town, 20 homes were randomly selected and a member of the family was interviewed (a total of 300 interviews) during the morning or afternoon. The questionnaires and photographs of the identified specimens of each Jatropha species were used for the interview (Martínez-Gordillo, Fernández-Casas, 

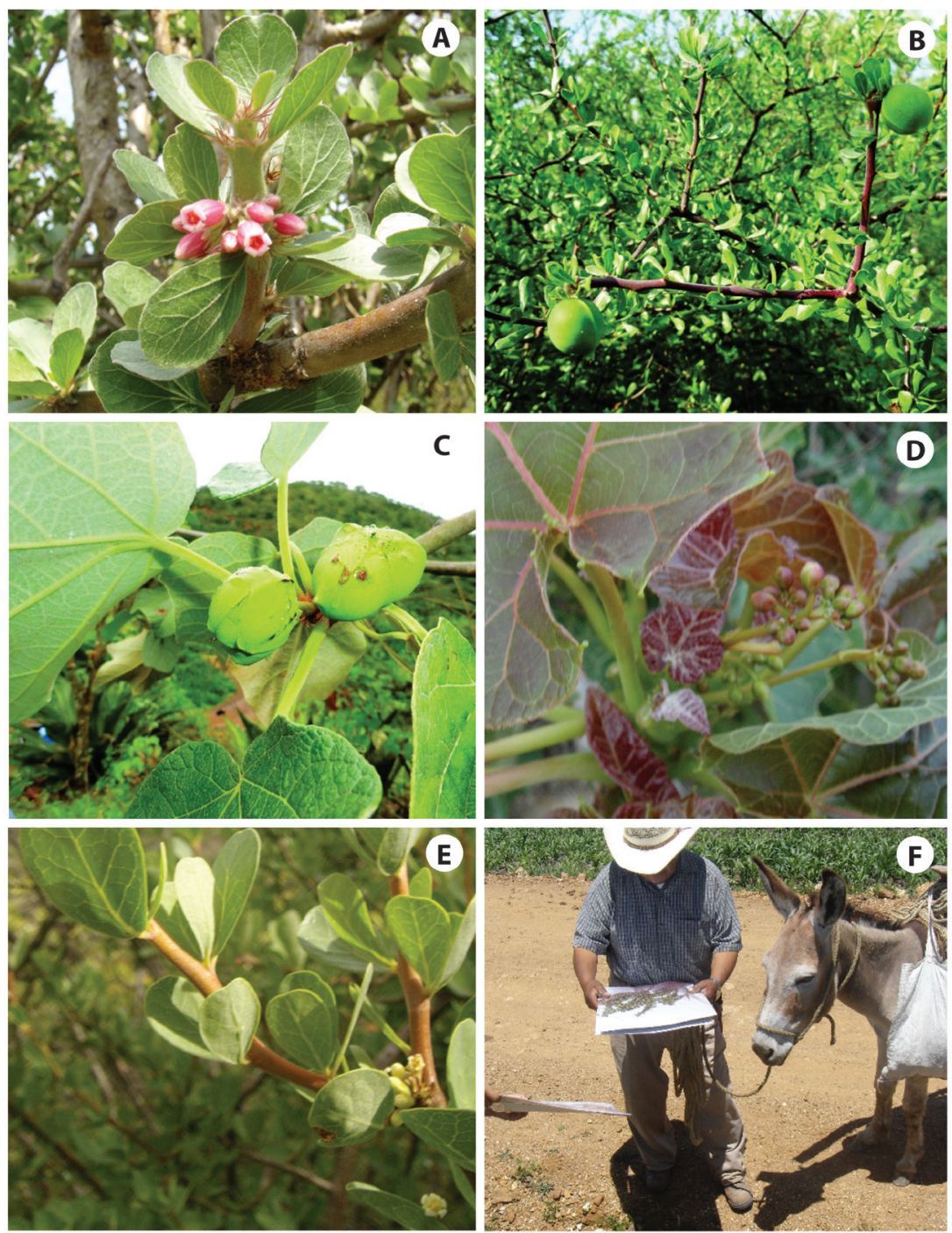

Fig. 2. Jatropha species distributed in the Tehuacán-Cuicatlán Biosphere Reserve: A) J. neopauciflora Pax.; B) J. rzedowskii J. Jiménez Ram.; C) J. rufescens Brandegee; D) J. ciliata Sessé ex Cerv.; E) J. oaxacana J. Jiménez Ram. \& R. Torres; and F) interviewer.

Jiménez-Ramírez, Ginez-Vázquez, \& VegaFlores, 2014).

The data were used to estimate the following indexes:

- $\quad$ Significant Use Level $=$ Number of citation for the species $i$ / Number of informants

- Criterion: Those uses cited with a frequency equal to or above $20 \%$ could be considered important from the perspective of cultural acceptance and, therefore, deserve evaluation and scientific validation (Germosen-Robineau, 1995).

- $\quad$ Relative Use Value for the species = Number of uses for the species $i /$ Total number of interviewees X 100 .

Seed collecting: Permission for seed collecting was obtained from the Secretaria de Medio Ambiente y Recursos Naturales 
(SEMARNAT, access document SGPA/ DGGFS/ 712/ 3439/ 12); additionally, the approval of the local authorities of each town were obtained. Due to seed availability, the collection sites were limited to Zapotitlán de las Salinas and Santa Ana Teloxtoc, state of Puebla, and Casa Blanca and La Mexicana, state of Oaxaca, and only for J. rufescens, $J$. rzedowskii, and J. neopauciflora. From August to October of 2013, fruits were collected at maturity stage (fruits turning to yellow color) and dried under shaded area to about $8 \%$ seed moisture. The seed sample size per population varied from 350 to 1200 seeds, except J. rzedowskii from Zapotitlán with 20 seeds. Habitants of San Pedro Jaltepetongo mentioned that they had never observed fruits of $J$. ciliata and no fruits were found during the collecting period for J. oaxacana.

Seed chemical profile: Fifty dehulled seeds were ground in a mortar to flour powder to perform the chemical analysis on November 2013 and keep under refrigeration at $5^{\circ} \mathrm{C}$. Flour moisture was measured in $2 \mathrm{~g}$ of flour sample in a thermobalance moisture analyzer (OHAUS, $\mathrm{MB} 200$ ) at $95^{\circ} \mathrm{C}$ per $60 \mathrm{~min}$, according to the AOAC methods (1995). The AOAC (1995) methods were also applied to quantify the total lipids, crude protein, and ash. The lipids were measured in $3 \mathrm{~g}$ flour samples by the Soxhlet method; the crude protein was quantified in 0.4 g flour sample by the Kjendahl method; and 5 $\mathrm{g}$ of dehulled seed was used to determine the ash content.

Seed fatty acid profile: The oil from 20 dehulled seed was extracted with petroleum ether $\left(40\right.$ to $\left.60^{\circ} \mathrm{C}\right)$ in a ratio of $1: 20(\mathrm{w} / \mathrm{v})$ for 8 $\mathrm{h}$ under constant shaking at room temperature. After centrifugation, the solvent was removed with gaseous nitrogen. The methyl ester was obtained by the AOAC (1995) method. The fatty acids were analyzed by gas chromatography (GC-14A, Shimadzu, Japan), using an instrument with an autosampler (AOC-20 s, Shimadzu, Japan), autoinjector, a Carbowax Varian capillary column $(50 \mathrm{~m} \times 0.25 \mathrm{~mm}$
ID) and a flame ionization detector. The programmed temperature was 160 to $225^{\circ} \mathrm{C}$, with nitrogen as the carrier gas, at a flow of $1 \mathrm{~mL}$ $\min ^{-1}$. A mixture of methyl esters was run and the retention times were used to identify the sample peaks. The content of fatty acids was estimated in percentages, according to the total area of each of the peaks.

Seed phorbol esters: Phorbol esters were extracted and quantified using the method proposed by Makkar, Sidhuraju, and Becker (2007), based on Makkar, Aderibigbe, and Becker (1998) and recently used by Soto-León et al. (2014). In summary, a sample of $2 \mathrm{~g}$ of defatted flour, with $20 \mathrm{~mL}$ methanol was shaken for $30 \mathrm{~s}$ and centrifuged at $3500 \mathrm{rpm}$ to separate the supernatant, which was deposited in a flask and placed in a rotary evaporator. The obtained sample was transferred to a 15 $\mathrm{mL}$ Falcon tube to which $4 \mathrm{~mL}$ ethanol and 2 $\mathrm{mL}$ tetrahydrofurane were added. Using a thermoblock, the sample was concentrated to $2 \mathrm{~mL}$ and centrifuged at $15000 \mathrm{rpm}$ per $1.5 \mathrm{~min}$ at $5^{\circ} \mathrm{C}$ to be injected into an HPLC. The analytical column was a reverse phase $\mathrm{C} 18$ (LiChrospher 100, endcapped $5 \mathrm{~lm}$ ) $2504 \mathrm{~mm}$ I.D. column protected with a guard column containing the same material as the main one. The separation was performed at room temperature $\left(23^{\circ} \mathrm{C}\right)$ and the flow rate was $1.3 \mathrm{~mL} \cdot \mathrm{min}^{-1}$. As a standard, phorbol 12-myristate-13-acetate (Sigma) with a retention time of $25 \mathrm{~min}$ was used. Four phorbol ester compound peaks that appeared between 23 and 26 min were identified and integrated at $280 \mathrm{~nm}$, in the standard. The results are expressed in $\mathrm{mg} . \mathrm{g}^{-1}$ flour, equivalent to the standard.

\section{RESULTS}

Characterization of traditional uses: Of the 300 programmed informants, 241 (80\%) were interviewed (104 female and 137 male); $47 \%$ were between the ages of 50 and 85 yearsold, $40 \%$ between 30 and 49 years-old, and 13 $\%$ between 11 and 29 years-old. The main 
occupations were housewife (36\%), farmer (40 $\%)$, merchant (10\%), and others (12\%).

The survey showed differences among the species, in terms of their common names, treatment use (for the case of medicinal use), part(s) of the plant used, preparation-administration, and estimated indexes (Table 2, 3). The uses recorded for the Jatropha species (with the exception of $J$. ciliata, for which no use was registered) were classified into medicinal, food, ornamental, and others. J. rufescens had restricted use, its leaves are utilized only to wrap fresh dairy products (Table 2,3 ).

Medicinal use of the latex and tea from leaves were the most frequently cited among the interviewees, mainly for $J$. neopauciflora, which is used to treat 13 disorders, in contrast with $J$. rzedowskii and J. oaxacana which are used to treat two and one disorders, respectively (Table 2, 3). The medicinal use for J. neopauciflora had the highest Significant Use Level, the most prominent uses being for dental problems (toothache, sensitivity, caries, bad breath, yellowish teeth, and looseness of teeth) $35.4 \%$, and oral diseases (oral herpes, gingivitis, and oral candidiasis) $32.9 \%$. In addition, it is also used to treat hemorrhages with a Significant Use Level of $7.4 \%$. J. rzedowskii and J. oaxacana are also used to cure dental problems and to heal lesions, but the Significant Use Level for both is very low $(0.4 \%)$. The component of the plant utilized to treat these disorders is the latex, which is applied directly or tea from stem or leaves taken orally and applied directly on the lesion (Table 2, 3).

The values for seed used as food were not important, with a relative frequency below 20 \%: 7.8, 2.1 and $10.7 \%$ for J. neopauciflora, $J$. oaxacana, and J. rzedowskii, respectively (Table 2, 3). Specifically, in eight of the 15 towns, informants said that the seeds are eaten raw, roasted, and cooked in some regional food-dishes. It is important to highlight that the interviewees noted that eating the raw seed in large quantities can produce headache, digestive disorders, and vomiting.

The Relative Use Values were 9.1, 2.9, 1.6, and $0.4 \%$ for $J$. neopauciflora, J. oaxacana,
$J$. rzedowskii, and $J$. rufescens, respectively (Table 2, 3). On the other hand, none use was reported for $J$. ciliata. These data indicate that $J$. neopauciflora is the most used species in the Tehuacán-Cuicatlán Biosphere Reserve.

Seed chemical profile: A slight variation in the compounds of the chemical profile was detected (Table 4). The flour moisture content was between 3.96 and $4.48 \%$. The crude protein content was between 23.37 and $26.02 \%$ with slight variation among the species, and a sample provenance for the case of $J$. neupauciflora.

Seed fatty acid profile: Four saturated and six unsaturated fatty acids were detected (Table 4). The most abundant saturated fatty acids are palmitic and stearic, whose ranges are 10.11 to $15.50 \%$ and 9.47 to $11.15 \%$, respectively. The most abundant unsaturated fatty acids are oleic and linoleic, with ranges from 25.08 to $30.09 \%$ and from 44.55 to 48.46 $\%$, respectively (Table 4 ). The ricinoleic acid was present in two samples of $J$. neopauciflora, $0.11 \%$ on average. The people of the Tehuacán-Cuicatlán Biosphere Reserve eat raw $J$. neopauciflora dehulled seed in small quantities, with no apparent digestive effects.

Seed phorbol esters: There were no phorbol ester compounds peaks detected in the seed samples of $J$. rufescens, $J$. rzedowskii, and $J$. neopauciflora (Table 4), according to the standard method used. Therefore, three new Jatropha species phorbol esters (free compounds) were added to the worldwide short list so far.

\section{DISCUSSION}

Of the interviewed informants in Tehuacán-Cuicatlán Biosphere Reserve, it was evident that the knowledge on the use of Jatropha species ( $J$. neopauciflora, J. rzedowskii, J. oaxacana, and $J$. rufescens) is concentrated in the housewives and farmers older than 30 years, which reflects the lack of transfer of knowledge to younger generations. Jatropha 


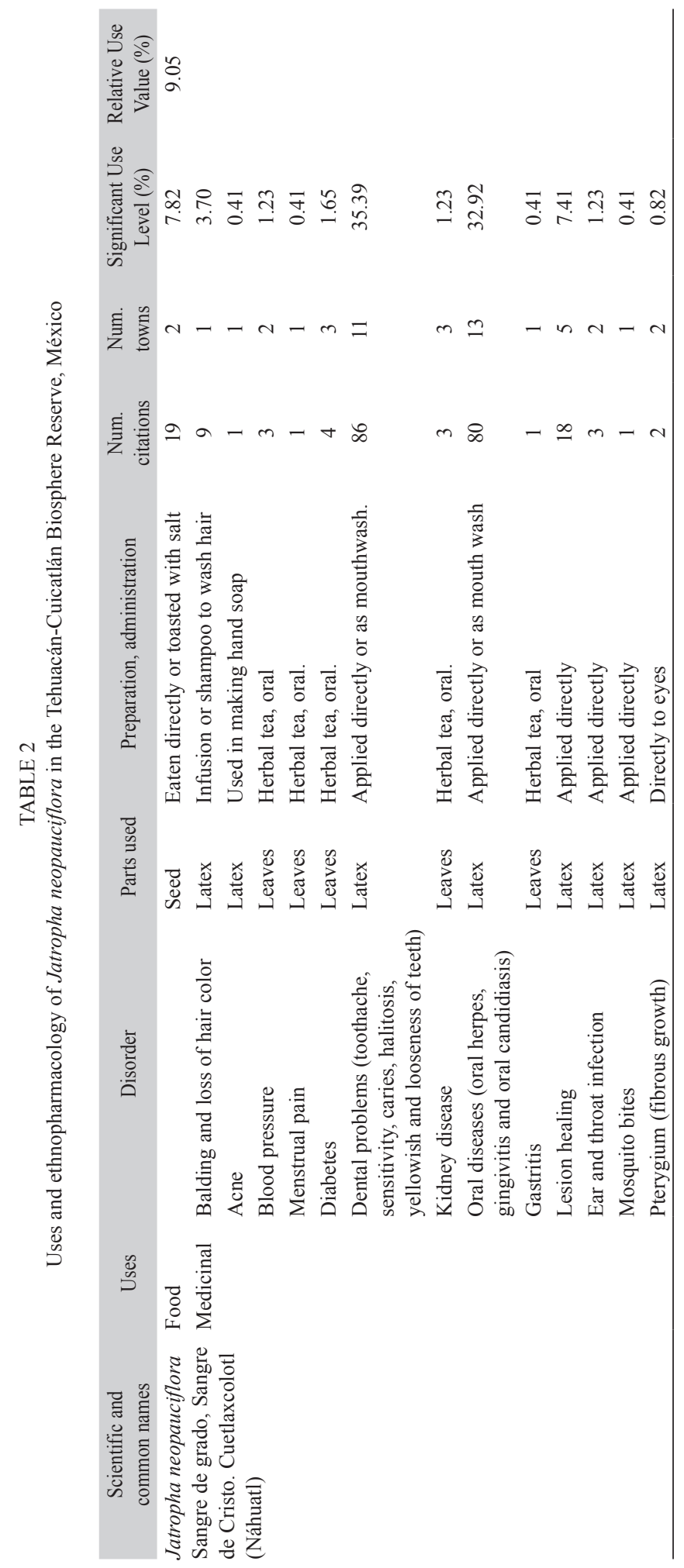




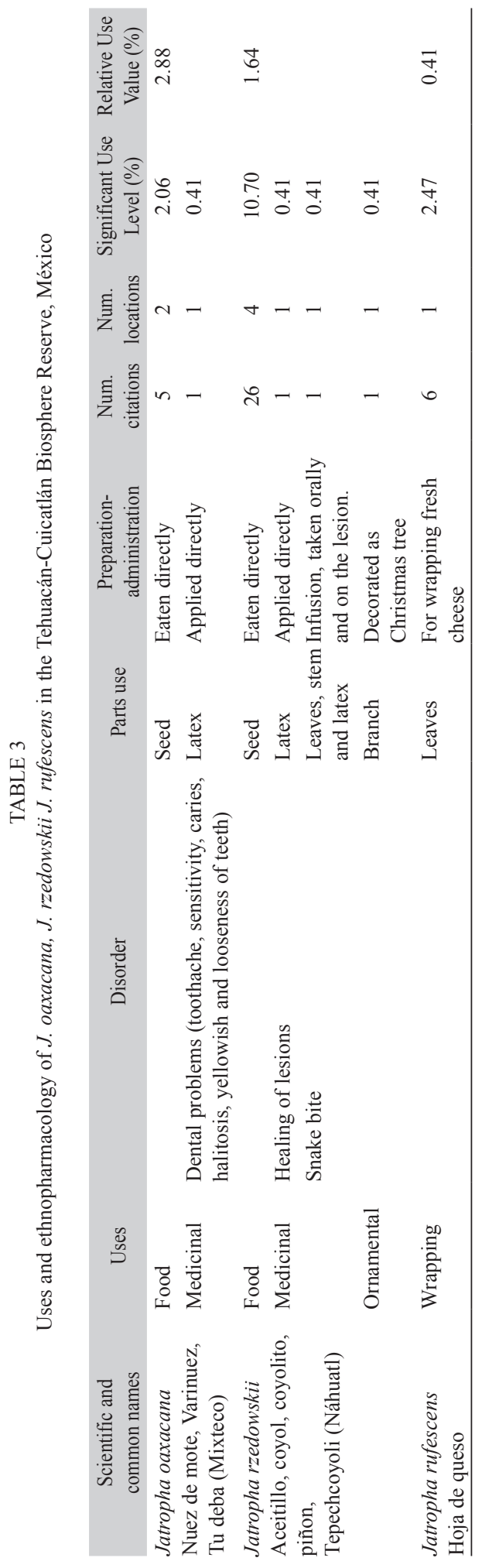

species were used mainly as medicinal, and less frequently as food, which is reflected by little cultural acceptance of the seed, associated with the cause of digestive disorders when the seed is eated row in considerable quantities.

Medicinal use was the most frequently cited among the interviewees and $J$. neopauciflora had the highest Significant Use Level. This may be associated to its wide distribution in the study area and to the latex bactericidal properties documented by Canales et al. (2005), as having high effectiveness against 14 bacterial strains. This use is in accordance with the Greek rot of jatros (physician) and all the findings on the medical application for several species, as an example we cited the review of Abdelgadir and Staden (2013).

Regarding mouth disorders caused by fungi and oral thrush [candidiasis caused by the fungus Candida albicans (C.P. Robin) Berkhout], they mentioned to traditionally treat it with latex from leaves and stems of $J$. neopauciflora. This treatment is documented here for the first time, with a high Significant Use Level (32.9\%). According to Germosén-Robineau (1995), with this Significance Level, the antimycotic use deserves evaluation and scientific validation, as has been done for other species, such as Jatropha multifida L., whose latex was demonstrated to have anti-fungal activity, that is highly effective for more than one strain of fungus (Hamza et al., 2006). Anti-fungal activity against Sporothrix schenckii and Fusarium proliferatum has also been demonstrated in crude extracts from underground parts of $J$. isabellei (Kieling-Fröhlich et al., 2013).

The use of J. neopauciflora to treat lesions is probably due to the hemostatic activity, however, this needs to be corroborated in laboratory tests. The use of the latex to heal lesions has also been observed in J. gossypifolia L. (Oduola et al., 2005) and J. curcas L. (Osoniyi \& Onajobi, 2003). For J. rzedowskii, its antioxidant activity and vasoconstrictor effect which helps in healing wounds, have been documented (Escobedo-Martínez, Reyes-Ramírez, GarcíaArredondo, Rojas-Molina, \& Enríquez, 2013), although they warns that the effectiveness of 
TABLE 4

Chemical profile of dehulled-seed of three species of Jatropha in the Tehuacán-Cuicatlán Biosphere Reserve, México

\begin{tabular}{|c|c|c|c|c|c|}
\hline Compound & $\begin{array}{c}\text { J. rufescens } \\
\text { (La Mexicana) }\end{array}$ & $\begin{array}{l}\text { J. rzedowskii } \\
\text { (Casa Blanca) }\end{array}$ & $\begin{array}{l}\text { J. rzedowskii }{ }^{1} \\
\text { (Zapotitlán) }\end{array}$ & $\begin{array}{l}\text { J. neopauciflora } \\
\text { (S. A. Teloxtoc) }\end{array}$ & $\begin{array}{l}\text { J. neopauciflora } \\
\text { (Zapotitlán) }\end{array}$ \\
\hline Moisture & 4.06 & 4.11 & --- & 3.96 & 4.48 \\
\hline Protein $(\%)$ & 23.37 & 24.94 & --- & 24.11 & 26.02 \\
\hline Fatty acids $(\%)$ & 36.60 & 34.79 & --- & 35.3 & 35.49 \\
\hline Ash $(\%)$ & 3.67 & 2.86 & --- & 2.80 & 2.53 \\
\hline \multicolumn{6}{|l|}{ Saturated fatty acids } \\
\hline Myristic $\left(\mathrm{C}_{14} \mathrm{H}_{28} \mathrm{O}_{2}\right)$ & 0.83 & 0.24 & --- & 0.74 & 0.77 \\
\hline Palmitic $\left(\mathrm{C}_{16} \mathrm{H}_{32} \mathrm{O}_{2}\right)$ & 10.11 & 13.63 & --- & 16.50 & 14.84 \\
\hline Margaric $\left(\mathrm{C}_{17} \mathrm{H}_{34} \mathrm{O}_{2}\right)$ & 0.14 & 0.13 & --- & 0.14 & 0.14 \\
\hline Stearic $\left(\mathrm{C}_{19} \mathrm{H}_{38} \mathrm{O}_{2}\right)$ & 9.65 & 9.95 & --- & 9.47 & 11.15 \\
\hline \multicolumn{6}{|l|}{ Unsaturated fatty acids } \\
\hline Palmitoleic $\left(\mathrm{C}_{16} \mathrm{H}_{30} \mathrm{O}_{2}\right)$ & 0.28 & 1.01 & --- & 0.71 & 0.70 \\
\hline Oleic $\left(\mathrm{C}_{18} \mathrm{H}_{34} \mathrm{O}_{2}\right)$ & 30.05 & 30.09 & --- & 26.73 & 25.08 \\
\hline Linoleic $\left(\mathrm{C}_{18} \mathrm{H}_{32} \mathrm{O}_{2}\right)$ & 48.46 & 44.55 & --- & 45.07 & 46.64 \\
\hline Linolenic $\left(\mathrm{C}_{19} \mathrm{H}_{32} \mathrm{O}_{2}\right)$ & 0.25 & 0.14 & --- & 0.35 & 0.37 \\
\hline Arachidonic $\left(\mathrm{C}_{21} \mathrm{H}_{42} \mathrm{O}_{2}\right)$ & 0.12 & 0.14 & --- & 0.07 & 0.10 \\
\hline Ricinoleic $\left(\mathrm{C}_{19} \mathrm{H}_{36} \mathrm{O}_{3}\right)$ & ND & ND & --- & 0.10 & 0.12 \\
\hline Phorbol esters ( $\left.\mathrm{mg} \mathrm{g}^{-1}\right)$ & ND & ND & ND & ND & ND \\
\hline
\end{tabular}

1 A small seed sample of this species was obtained and only phorbol esters were determined.

the extracts is reduced if vascular endothelial cells are lacking. Anticoagulant and antioxidant activity and absence of cytotoxic effect has been demonstrated in crude extract from leaves of $J$. gossypiifolia (Félix-Silva et al., 2014). All these findings may explain the positive results observed by people in the TehuacánCuicatlán Biosphere Reserve when they use the latex of Jatropha spp.

Data of the Relative Use Values indicated that $J$. neopauciflora is the most used species in the Tehuacán-Cuicatlán Biosphere Reserve, possibly associated with its extensive regional distribution (Hernández-Nicolás et al., 2015). On the other hand, no use was reported for $J$. ciliata and only one use was reported for $J$. rufescens. The distribution of both species was limited to one small population, and Hernández-Nicolas et al. (2015) have stated that both species were at extinction risk. These statements may also explain their restrictive use.

The flour moisture content and crude protein were similar to those reported by Bautista (2010) for accessions of $J$. curcas, $4.5 \%$ and
$25.1 \%$, respectively. The crude protein content was within the expected range (19 to $33 \%$ ) in according to Martínez, Martínez, Makkar, Francis, and Becker (2010) for J. curcas, but lower than the reported for $J$. cinerea $(57 \%)$ (Soto-León et al., 2014). The fatty acid content was lesser than percent values reported for J. curcas $63 \%$ (Akbar, Yaakob, Kamarudin, Ismail, \& Salimon, 2009) and $45 \%$ (Makkar et al., 1998; Bautista, 2010; Martínez et al., 2010 ), as well as the $66 \%$ reported for J. cinerea (Soto-León et al., 2014).

Four saturated and six unsaturated fatty acids were detected. The most abundant saturated fatty acids were palmitic and stearic, which concentrations were higher than those obtained in $J$. cinerea ( 8.8 and $6.4 \%$ ), respectively (Soto-León et al., 2014). Ovando-Medina, Espinosa-Garcia, Núñez-Farfan, and SalvadorFigueroa (2011) reported in samples of $J$. curcas $12.8 \%$ palmitic and $6.1 \%$ stearic acids; the latter is slightly below those of our study. Also in $J$. curcas, Martínez-Herrera et al. (2006) found $10.5-13.0 \%$ palmitic and $2.3-2.8 \%$ 
stearic acids. Heller (1996) reported $15.4 \%$ palmitic acid and $6.2 \%$ stearic acid, similar to those reported in J. curcas (Akbar et al., 2009). In all these cases, the stearic acid content is lower than the values obtained in the three Jatropha species of our study.

The most abundant unsaturated fatty acids were oleic and linoleic. Ovando-Medina et al. (2011) reported averages of the acids of 38.7 and $40.7 \%$, respectively, in J. curcas, percentages similar to our study. Martínez-Herrera et al. (2006) informed 41.5 to $48.8 \%$ oleic and 34.6 to $44.4 \%$ linoleic for $J$. curcas, while Heller (1996) found $40.2 \%$ oleic and $36.3 \%$ linoleic acids. Akbar et al. (2009) reported 44.7 $\%$ oleic and $32.8 \%$ linoleic in J. curcas. SotoLeón et al. (2014) detected $34 \%$ oleic and 50 $\%$ linoleic in $J$. cinerea. As it can be observed there is a lot of variation in the concentration of these fatty acids, which may be attributed to the genetic changes, environmental conditions and their interaction.

Ricinoleic acid was present in two samples of $J$. neopauciflora. Ovando-Medina et al. (2011) also found this acid in toxic J. curcas samples collected in Chiapas, México but it has not been found in samples of the non-toxic ecotype of the same species. Ricinoleic acid has concentrations of $90 \%$ in castor seeds (Ricinus communis L.), a species belonging to the same family as the genus Jatropha (Tunaru, Althoffa, Nüsingb, Dienerc, \& Offermanns, 2012). According to this author, ricinoleic acid acts as a laxative and induces childbirth because it intervenes in the cellular activity of the smooth muscle of both the intestine and the uterus. Information was not found in the literature on the dosage that causes these effects. People of the Tehuacán-Cuicatlán Biosphere Reserve eat raw $J$. neopauciflora dehulled seed in small quantities with no apparent digestive effects.

Phorbol esters were not detected in the seed of $J$. rufescens, J. rzedowskii, and $J$. neopauciflora. These findings are a highly relevant contribution of this study because few species are free of phorbol esters, and the absence of these compounds increases the possibility of use the seeds for human and animal consumption. Phorbol esters are present in the ecotypes of $J$. curcas (Maguly et al., 2015), J. elliptica (Pohl) Oken, J. glauca Vahl, J. gossypifolia, J. aceroides (Pax \& K.Hoffm.) Hutch. J. macrantha Müll. Arg., and J. integerrima Jacq. (Popluechai et al., 2009), making their consumption impossible.

However, even though phorbol esters were not detected in the oil, the dehulled seed may contain other antinutritional compounds of a thermolabile nature, such as inhibitors of trypsin, lectins, and phytates. Thus, it is recommended to toast or cook the seed because the high temperature facilitates the elimination of these compounds (Makkar et al., 2011). This may be the explanation for why, without knowing the exact reason, the people of the studied region said that it is better to eat the dehulled seed roasted.

In summary, the Significant Use Level of Jatropha species was low, with little cultural acceptance and sporadic utilization. The Relative Use Value was important for medicinal purposes, especially $J$. neopauciflora. The dehulled seeds of Jatropha spp. are potentially useful as food, having high protein contents, unsaturated oleic and linoleic fatty acids, and non-toxic phorbol esters.

\section{ACKNOWLEDGMENTS}

The authors thank the National System of Plant Genetic Resources (SINAREFI-SAGARPA) for funding this study, the personnel of the Tehuacán-Cuicatlán Biosphere Reserve (CONANP-SEMARNAT) for facilitating the fieldwork, and the authorities and inhabitants of the towns for their participation in the project.

\section{RESUMEN}

Usos tradicionales y composición química de la semilla de Jatropha spp. (Euphorbiaceae) en TehuacánCuicatlán, México. La Reserva de la Biosfera TehuacánCuicatlán, México contiene riqueza genética y endemismo para el género Jatropha, pero se desconoce el uso específico de las plantas y la composición química de la semi1la. Documentamos las formas tradicionales de uso de las especies de Jatropha y, analizamos la composición 
química de las semillas de las especies de Jatropha. En 15 comunidades se aplicaron 20 entrevistas semiestructuradas entre mayo y agosto de 2012 para estimar el Nivel de Uso Significativo y el Valor de Uso Relativo por especie. Se colectó semilla solo de $J$. neopauciflora, J. rufescens, y $J$. rzedowskii entre agosto y octubre de 2013 para determinar mediante los métodos de la AOAC, el contenido total de lípidos en una muestra de $3 \mathrm{~g}$ de harina mediante el método de Soxhlet, proteína cruda en una muestra de harina de 0.4 g por el método Kjendahl y ceniza en una muestra de $5 \mathrm{~g}$ de harina. El perfil de ácidos grasos se determinó por cromatografía de gases y el contenido de ésteres de forbol mediante HPLC. Las especies registradas fueron $J$. neopauciflora, $J$. oaxacana, J. rufescens, J. rzedowskii y $J$. ciliata, que se usan en medicina tradicional, alimento y como ornamental, excepto J. ciliata, para la cual no se reportó ningún uso. El Nivel de Uso Significativo como alimento no fue importante, pero para propósitos medicinales $J$. neopanciflora tuvo el mayor Valor de Uso Relativo (9.0 \%). El látex es usado para tratar 13 trastornos, incluyendo problemas dentales y enfermedades bucales con un Nivel Significativo de Uso de $32.9 \%$; y también es usada como hemostático. El contenido de proteína entre especies varió de 23.37 a 26.06 \% y los lípidos totales variaron de 34.79 a $36.60 \%$. Los principales ácidos grasos insaturados fueron oleico (25.08 a $30.09 \%$ ) y linoleico (44.55 a $48.46 \%$ ); los ácidos grasos saturados fueron palmítico (10.11 a $16.50 \%$ ) y esteárico ( 9.47 a $11.15 \%)$. No se detectó la presencia de ésteres de forbol (la causa principal de la toxicidad de la semilla) en $J$. neopauciflora, J. rufescens, y J. rzedowskii. En conclusión, el Nivel de Uso Significativo de las especies de Jatropha fue bajo, con poca aceptación cultural y utilización esporádica. El Valor de Uso Relativo fue importante para propósitos medicinales, especialmente para $J$. neopauciflora. Las semillas sin testa de J. neopauciflora, J. rufescens, y J. rzedowskii son potencialmente útiles como alimento por su alto contenido de proteínas, ácidos grasos insaturados oleico y linoleico. Se identificaron tres especies no toxicas de Jatropha. Se recomienda validar científicamente el uso antimicótico del látex de J. neopauciflora.

Palabras clave: ácidos grasos; ésteres de forbol; higiene dental; infecciones; Jatropha; proteínas; usos tradicionales.

\section{REFERENCES}

Abdelgadir, H. A., \& Staden J. V. (2013). Ethnobotany, ethnopharmacology and toxicity of Jatropha curcas L. (Euphorbiaceae): A review. South African Journal of Botany, 88, 204-218.

Agbogidi, O. M., Akparobi, S. O., \& Eruotor, P. G. (2013). Health and environmental benefits of Jatropha curcas L. Applied Science Reports, 1, 36-39.

Aiyelaagbe, O. O., Adesogan, E. K., Ekundayo, O., \& Adeniyi, B. A. (2000). The antimicrobial activity of roots of Jatropha podagrica (Hook). Phytotherapy Research, 14, 60-62.

Akbar, E., Yaakob, Z., Kamarudin, S.K., Ismail, M., \& Salimon, J. (2009). Characteristic and composition of Jatropha curcas oil seed from Malaysia and its potential as biodiesel feedstock. European Journal of Scientific Research, 29, 396-403.

Alexiades, M. (1996). Selected guidelines for: Ethnobotanical research: A field manual. New York: New York Botanical Garden.

Ankli, A., Sticher, O., \& Heinrich, M. (1999). Medical ethnobotany of the Yucatec Maya: Healers' consensus as a quantitative criterion. Economic Botany, 53, 144-160.

AOAC (Association of Analytical Communities). (1995). Official methods of analysis of the Association of Analytical Chemist (15th ed). Washington D.C.: AOAC.

Baraguey, C., Blond, A., Correia, I., Pousset, J. L., Bodo, B., \& Auvin-Guette, C. (2000). Mahafacyclin A, a cyclic heptapeptide from Jatropha mahafalensis exhibiting $\beta$-bulge conformation. Tetrahedron Letters, 41, 325-329.

Bautista, R. E. (2010). Tolerancia a la desecación y caracterización química de semillas de piñón mexicano (Jatropha curcas L.) colectadas en el Totonacapan. Tesis de Maestría, Colegio de Postgraduados, México.

Bruni, A., Ballero, M., \& Poli, F. (1997). Quantitative ethnopharmacological study of the Campidano valley and Urzulei district, Sardinia, Italy. Journal of Ethnopharmacology, 57, 97-124.

Bullangpoti, V., Khumrungsee, N., Pluempanupat, W., Kainoh, Y., \& Saguanpong, U. (2011). Toxicity of ethyl acetate extract and ricinine from Jatropha gossypifolia senescent leaves against Spodoptera exigua Hubner (Lepidoptera: Noctuidae). Journal of Pesticide Science, 36, 260-263.

Canales, M., Hernández, T., Caballero, J., Romo de Vivar, A., Ávila, G., Duran, A., \& Lira, R., (2005). Informant consensus factor and antibacterial activity of the medicinal plants used by the people of San Rafael Coxcatlán, Puebla, México. Journal of Ethnopharmacology, 97, 429-439.

DOF (Diario Oficial de la Federación). (1998). Decreto por el que se declara Área Natural Protegida, con el carácter de Reserva de la Biosfera, a la región denominada Tehuacán-Cuicatlán, ubicada en los estados de Oaxaca y Puebla. Estados Unidos Mexicanos: Presidencia de la República. Retrieved from http: http://www.dof.gob.mx/nota_detalle.php?codigo $=48$ 93340\&fecha $=18 / 09 / 1998$

Escobedo-Martínez, C., Reyes-Ramírez, I. E., GarcíaArredondo, A., Rojas-Molina, A., \& Enríquez, 
H. R. G. (2013). Estudios farmacológicos preliminares: actividad antioxidante y vasoconstrictora de extractos orgánicos provenientes de la planta medicinal Jatropha rzedowskii, colectada en la Reserva del Valle de Tehuacán-Cuicatlán. In: Memorias de la $9^{a}$ Reunión Internacional de Investigación en Productos Naturales. (p 147). México: Universidad Autónoma del Estado de Hidalgo.

Félix-Silva, J., Souza, T., Gomes-Camara, R. B., Cabral, B., Silva-Júnior, A. A., Moretti-Rebecchi, I. M., Zucolotto, S. M., Oliveira-Rocha, H. A., \& Fernandes-Pedrosa, M. F. (2014). In vitro anticoagulant and antioxidant activities of Jatropha gossypiifolia L. (Euphorbiaceae) leaves aiming therapeutical applications. Complementary and Alternative Medicine, 14, 405-418.

García, E. (1990). Climas, 1: 4000 000. IV.4.10 (A). Atlas Nacional de México, Volumen 2. México: Instituto de Geografía, UNAM.

Germosén-Robineau, L. (1995). Hacia una Farmacopea Vegetal Caribeña, Edición Tramil 7. Santo Domingo: Enda Caribe, UAG \& Universidad de Antioquia.

Hamza, O. J. M., Van den Bout-Van den Beukel, C. J. P., Matee, M. I. N., Moshi, M. J., Mikx, F. H. M., Selemani, H. O., Mbwambo, Z. H., Van der Ven, A. J. A. M., \& Verweij, P. E. (2006). Antifungal activity of some Tanzanian plants used traditionally for the treatment of fungal infections. Journal of Ethnopharmacology, 108, 124-132.

Heller, J. (1996). Physic Nut Jatropha curcas L. promoting the conservation and use of underutilized and neglected crops. 1. Rome: International Plant Genetic Resources Institute IPGRI. Retrieved from http:// www.bioversityinternational.org/uploads/tx_news/ Physic_nut_Jatropha_curcas_L._161.pdf

Hernández-Nicolás, N. Y., Córdova-Téllez, L., RomeroManzanares A., Jiménez-Ramírez J., Lobato-Ortiz R., \& Sánchez-Cuevas, J. A. (2015). Diagnóstico ecológico para la conservación de Jatropha spp. (Euphorbiaceae) y sus hábitats, en la Reserva Tehuacán-Cuicatlán, México. Revista de Biología Tropical, 63, 23-33.

Hidalgo-Báez, D., Ricard, M., Gaviria, J., \& Estrada, J. (1999). Aportes a la etnofarmacología de los Páramos Venezolanos. Ciencia, 7, 23-32.

Kieling-Fröhlich, J., Forbrig-Froeder, A. L., Janovik, V., Pozzebon-Venturini, T., Picada- Pereira, R., Augusti-Boligon, A., Faccim de Brum, T., Hartz-Alves, S., Teixeira da Rocha, J.B., \& Linde-Athayde, M. (2013). Antioxidant capacity, antimicrobial activity and triterpenes isolated from Jatropha isabellei Müll Arg. Natural Product Research, 27, 1049-1059.

Kumar A., \& Sharma S. (2008). An evaluation of multipurpose oil seed crop for industrial uses (Jatropha curcas L.): A review. Industrial Crops and Products, 28, 1-10.

Maghuly, F., Jankowicz-Cieslak, S. P., Till, B. J., \& Laimer, M. (2015). Geographic origin is not supported by the genetic variability found in a large living collection of Jatropha curcas with accessions from three continents. Biotechnology Journal, 10, 536-551.

Makkar, H. P. S., Aderibigbe, A. O., \& Becker, K. (1998). Comparative evaluation of non-toxic and toxic varieties of Jatropha curcas for chemical composition, digestibility, protein degradability and toxic factors. Food Chemistry, 62, 207-215.

Makkar, H. P. S., Kumar, V., Oyeleye, O. O., Akinleye, A. O., Angulo-Escalante, M., \& Becker, K. (2011). Jatropha platyphylla, a new non-toxic Jatropha species: Physical properties and chemical constituents including toxic and antinutritional factors of seeds. Food Chemistry, 125, 63-71.

Makkar, H. P. S., Siddhuraju, P., \& Becker, K. (2007). Plant secondary metabolites. Methods in molecular biology, 393. Totowa, NJ: Humana Press.

Martínez-Gordillo, M., Fernández-Casas, F. J., JiménezRamírez, J., Ginez-Vázquez, L. D., \& Vega-Flores, K. (2014). Euphorbiaceae Subfamilia Crotonoideae. In R. Medina-Lemos, Flora del Valle de TehuacánCuicatlán (pp. 1-84). México: Instituto de Biología, Universidad Nacional Autónoma de México.

Martínez, G. M., Jiménez, R. J., Cruz, D. R., Juárez, A., García, R., Cervantes, A., \& Mejía, H. R. (2002). Los géneros de la familia Euphorbiaceae en México. Anales del Instituto de Biología de la Universidad Nacional Autónoma de México, Serie Botánica, 73, 55-281.

Martínez, H. J., Martínez, A. A. L., Makkar, H., Francis, G., \& Becker, K. (2010). Agroclimatic conditions, chemicals and nutritional characterization of different provenances of Jatropha curcas L. from México. European Journal Science Research, 39, 396-407.

Martínez-Herrera, J., Siddhuraju, P., Francis, G., DávilaOrtíz, G., \& Becker, K. (2006). Chemical composition, toxic/antimetabolic constituents, and effects of different treatments on their levels, in four provenances of Jatropha curcas L. from Mexico. Food Chemistry, 96, 80-89.

Murray, S. (1988). Estadística (Segunda Edición). España: McGraw Hill, Madrid.

Oduola, T., Adeosun, G. O., Oduola, T. A., Avwioro, G. O., \& Oyeniyi, M. A. (2005). Mechanism of action of Jatropha gossypifolia stem latex as a hemostatic agent. European Journal of General Medicine, 2, 140-143.

Osoniyi, O., \& Onajobi, F. (2003). Coagulant and anticoagulant activities in Jatropha curcas latex. Journal of Ethnopharmacology, 89, 101-105. 
Ovando-Medina, I., Espinosa-Garcia, F. J., Núñez-Farfan, J., \& Salvador-Figueroa, M. (2011). Genetic variation in Mexican Jatropha curcas L. estimated with seed oil fatty acids. Journal of Oleo Science, 60, 301-311.

Popluechai, S., Breviario, D., Mulpuri, S., Makkar, H. P. S., Raorane, M., Reddy, A. R., Palchetti, E., Gatehouse, A.M.R., Keith, S. J., O’Donnell, A. G., \& Kohli, A. (2009). Narrow genetic and apparent phenetic diversity in Jatropha curcas: Initial success with generating low phorbol ester interspecific hybrids. Nature Precedings. hdl:10101/npre.2009.2782.1 Posted 13 Jan 2009.

Reddy-Prasad, D. M., Izam, A., \& Rahman-Khan, M. M. (2012). Jatropha curcas: Plant of medical benefits. Journal of Medicinal Plants Research, 6, 2691-2699.
Soto-León, S., López-Camacho, E., Milán-Carrillo, J., Sánchez-Castillo, M. A., Cuevas-Rodríguez, E., Picos-Corrales, L. A., \& Contreras-Andrade, I. (2014). Jatropha cinerea seed oil as a potential nonconventional feedstock for biodiesel produced by an ultrasonic process. Revista Mexicana de Ingeniería Química, 13, 739-747.

Tunaru, S., Althoffa, T. F., Nüsingb, R. M., Dienerc, M., \& Offermanns, S. (2012). Castor oil induces laxation and uterus contraction via ricinoleic acid activating prostaglandin EP3 receptors. Proceedings of the National Academy of Sciences United States, 109, 9179-9184.

Webster, G. L. (1994). Synopsis of the genera and suprageneric taxa of Euphorbiaceae. Annals of the Missouri Botanical Garden, 81, 33-144. 